\title{
THE PROBLEM OF LOW PEAK CONCENTRATION OF GENTAMICIN IN CLINICAL PRACTICE
}

\author{
${ }^{1,2}$ Göböová, M. $-{ }^{2}$ Kuželová, M. $-{ }^{2}$ Foltánová, T. \\ ${ }^{1}$ Teaching hospital Nitra, Department of Clinical Pharmacology \\ ${ }^{2}$ Comenius University in Bratislava, Faculty of Pharmacy, \\ Department of Pharmacology and Toxicology
}

\begin{abstract}
Aminoglycoside antibiotics have particular importance in the treatment of Gram-negative infections. Toxicity of gentamicin is well-known, but patients often receive insufficient dosage in clinical practice. The purpose of this study was to refer to the problem of insufficient dosages that were confirmed by low peak concentration and to determine relationship between low peak levels and pharmacokinetic parameters, renal function and body weight.

We studied 68 patients who were treated with gentamicin for one year (August 2010 - August 2011). Therapeutic drug monitoring (TDM) was applied for all the patients. Gentamicin peak and trough concentrations were measured by the FPIA (Fluorescence Polarization Immunoassay) method with an analyser, AxSYM of ABBOTT company. We divided the patients into 3 groups according to peak and trough levels.

Together $13(19 \%)$ patients had high trough concentrations and optimal peak concentrations. Only $6(9 \%)$ patients had optimal trough and peak levels in the first measurement of plasma concentrations. The third group included 49 patients $(72 \%)$. These patients had optimal trough levels and low peak levels in the first measurement. 34 patients of the third group (28 males, 6 females) had optimal peak levels after adjustment of dosage in the second measurement. 15 patients, only males did not reach optimal peak levels even after adjustment of dosage in the second measurement.

The patients with low peak levels of gentamicin are more frequent than patients with toxic adverse effects in clinical practice. Especially, these are the patients with higher value of body weight and following increased pharmacokinetic parameters: creatinine clearance, total volume of distribution, total clearance and elimination rate constant. The clinical pharmacists have to adjust dosage regimens, especially according to Therapeutic drug monitoring (TDM) and clinical experience. The results of the study have confirmed that the clinical pharmacists must adjust dose regimen not only for patients who require reduced doses but more often for patients who require higher doses than are commonly used in clinical practice. These patients are at risk of underdosing of aminoglycoside antibiotics.
\end{abstract}

Keywords: Gentamicin - Therapeutic Drug Monitoring (TDM) -Peak serum drug concentration 


\section{INTRODUCTION}

Aminoglycoside antibiotics are important in the treatment of Gram-negative infections and as synergistic agents for the treatment of staphylococcal and streptococcal (group B streptococci and enterococci) infections. However, these agents have a narrow therapeutic index. Thus, a number of new antibiotics have been introduced in an attempt to reduce the number of patients treated with aminoglycosides. Unfortunately, these new antibiotics tend to be costly, and are often associated with development of resistance and treatment failure. Data suggest that a pharmacokineticpharmacodynamic relationship exists for some aspects of efficacy and toxicity of aminoglycosides. Serum drug concentrations and tissue accumulation are related to the development of nephrotoxicity, and individualised pharmacokinetic monitoring may decrease rates of nephrotoxicity [1].

Peak serum drug concentrations and the ratio of $\mathbf{C m a x} / \mathbf{M I C}$ ( $8-10$ should be targeted) appear to correlate with clinical efficacy in the treatment of patients with bacterial infections. A method to improve antimicrobial dosing in individual patients is the trough application of therapeutic drug monitoring (TDM) [2].Therapeutic drug monitoring (TDM) has been used to optimise aminoglycoside therapy and reduce toxicity. Cost-effective approaches to drug selection and TDM are important considerations in the proper use of aminoglycosides $[1,3]$.

Aminoglycosides are concentration-dependent killing antibiotics, so that it is necessary to obtain elevated peak levels to reach the pharmacokineticpharmacodynamic objectives. Because of their nephrotoxicity, this class of antibiotics is frequently underprescribed and is given at an insufficient dosage when prescribed. That is why TDM of aminoglycosides is recommended to assess efficacy. Unfortunately, this TDM does not allow dosage adaptation on the first dose of aminoglycosides [4].

The cost of one-day therapy of gentamicin is lower than a therapy of amikacin. Toxicity of gentamicin is well-known, but patients are administered insufficient dosages in clinical practice. The purpose of this study was to refer to the problem of insufficient dosage that was confirmed by low peak concentrations and to determine the relationship between following pharmacokinetic (PK) parameters: actual body weight (ABW), lean body weight (LBW), ideal body weight (IBW), height, body mass index (BMI), creatinine $(\mathrm{Cr})$ and low peak levels.

\section{PATIENTS AND METHODS}

Our retrospective study includes 68 patients who were treated with gentamicin for one year (August 2010-August 2011). Dosing in our groups was the most frequent at $1.5-2 \mathrm{mg} / \mathrm{kg}$ every 12 hours. The patients were hospitalised in the surgery departments in the teaching hospital Nitra. Therapeutic drug monitoring was applied for all the patients. We divided them into 3 groups. The first group includes patients with high trough levels and optimal peak levels; the second group includes patients with both optimal levels and the third group includes patients with optimal trough levels but low 
peaks levels. The third group was divided into two subgroups A and B. The subgroup A includes patients who had optimal peak levels after an adjusted dosage regimen and the second B includes patients who had low peak levels further.

In the groups, we compared age, height, actual body weight (ABW), lean body weight (LBW), ideal body weight (IBW), height, body mass index (BMI), creatinine $(\mathrm{Cr})$, Cockcroft and Gault creatinine clearance $(\mathrm{CG}-\mathrm{ClCr})$, total volume of distribution (total $\mathrm{Vd}$ ), total clearance (total $\mathrm{Cl}$ ) and elimination rate constant $\left(\mathrm{k}_{\mathrm{e}}\right)$.

IBW for patients is based on their height according to insurance actuarial tables for longevity. LBW is patient's body weight minus fat weight. It is often used interchangeably with IBW. Obesity is another factor that affects the Cockcroft and Gault $\mathrm{Cr} \mathrm{Cl}$ estimation. Obesity is defined as $>20 \%$ over IBW [5]. Using IBW is still preferable to using $\mathrm{ABW}$; however, using an adjusted body weight $\left(\mathrm{BW}_{\mathrm{adj}}\right)$ between IBW and ABW may be more accurate. Use of a factor of $40 \%$ or $20 \%$ of the difference between $\mathrm{ABW}$ and IBW has been proposed. $\mathrm{BW}_{\mathrm{adj}}$ was calculated according to the formula: IBW +0.4 or $0.2 \times(\mathrm{ABW}-\mathrm{IBW}$ ) [6, 7]. Many authors have suggested the use of IBW or BW adj. $_{\text {. }}$

Gentamicin peak and trough concentrations were measured by the FPIA (Fluorescence Polarization Immunoassay) method with an analyser, AxSYM of ABBOTT company. The individual dosage regimens were determined according to The ABBOTTBASE - Pharmacokinetic system - Program, Abbott Laboratories, Abbott Park Illinois, version 1.10. The ABBOTTBASE - Pharmacokinetic system uses the principles of pharmacokinetics to help design and adjust dosage regimens. The software allows the use of general, population-based kinetic parameters when specific dosing information and serum drug levels are not available. The general parameters used in the software were determined from clinical studies. The population-based parameters assume that patient handles the drug in a manner similar to the study group.

Therapeutic range for gentamicin trough level is $<2 \mathrm{mg} / \mathrm{l}$. Therapeutic range for gentamicin peak level is $5-10 \mathrm{mg} / \mathrm{l}$ (for multiple daily regimens) [8].

We correlated peak serum concentration and age, height, ABW, LBW, IBW, height, $\mathrm{BMI}, \mathrm{Cr}, \mathrm{CG}-\mathrm{ClCr}$, total $\mathrm{Vd}$, total $\mathrm{Cl}$ and $\mathrm{k}_{\mathrm{e}}$.

All values are presented as mean $\pm \mathrm{SD}$. Statistical evaluation was performed using ANOVA test for characteristics of patient groups according to trough and peak concentration and an unpaired Student's t-test for characteristics of the patients in the subgroups and pharmacokinetic parameters according to peak concentration after a dosage adjustment in the second measurement. Values of $p<0.05$ were considered statistically significant.

\section{RESULTS AND DISCUSSION}

Together, $13(19 \%)$ patients had high trough concentrations and optimal peak concentrations (the first group). They were mostly elderly patients who had low value of ClCr. Only $6(9 \%)$ patients had optimal trough and peak levels in the first measurement of plasma concentrations (the second group). The third group includes 49 patients 
(72\%) (Tab. 1). We divided the third group into 2 subgroups A and B. The patients of both subgroups had optimal trough levels and low peak levels in the first measurement.

Table 1.Characterictics of the patient groups according to trough and peak concentrations

\begin{tabular}{|l|c|c|c|c|}
\hline \multicolumn{1}{|c|}{ Patients } & $\begin{array}{c}\text { Patient } \\
\mathbf{n}(\%)\end{array}$ & $\begin{array}{c}\text { Mean age } \\
\pm \text { SD } \\
\text { (year) }\end{array}$ & $\begin{array}{c}\text { CICr } \pm \text { SD } \\
\text { (ml/s) }\end{array}$ & $\begin{array}{c}\text { ABW } \pm \text { SD } \\
\text { (kg) }\end{array}$ \\
\hline $\begin{array}{l}\text { The first group } \\
\text { The patients with high trough } \\
\text { concentrations and optimal peak } \\
\text { concentrations }\end{array}$ & $\mathbf{1 3 ( 1 9 )}$ & $71.4 \pm 12.0^{*}$ & $1.05 \pm 0.49$ & $77.3 \pm 20.0$ \\
\hline $\begin{array}{l}\text { The second group } \\
\text { The patients with optimal trough } \\
\text { and peak levels in the first } \\
\text { measurement of plasma } \\
\text { concentrations }\end{array}$ & $\mathbf{6 ( 9 )}$ & $56.2 \pm 14.4$ & $1.86 \pm 1.36^{* * *}$ & $66.3 \pm 12.9$ \\
\hline $\begin{array}{l}\text { The third group } \\
\text { The patients with optimal trough } \\
\text { levels and low peak levels in the } \\
\text { first measurement }\end{array}$ & $\mathbf{4 9 ( 7 2 )}$ & $56.5 \pm 18.4$ & $1.98 \pm 1.05$ & $93.3 \pm 29.6$ \\
\hline
\end{tabular}

$\mathrm{n}$ - number of patients, $\mathrm{SD}$ - standard deviation, $\mathrm{ClCr}$ - clearance creatinine, $\mathrm{ABW}$ - actual body weight, $* p<0.05-$ mean age - the first group vs. the second group,

${ }^{* *} p<0.01 \mathrm{ClCr}-$ the third group vs. second group according to ANOVA test, but the small number of patients in the second group should be taken into consideration

Together 34 patients (28 males, 6 females) in subgroup A had optimal peak levels after a dosage adjustment in the second measurement. 15 patients in subgroup B(only males) did not have optimal peak levels after the adjustment of dosage in the second measurement. We determined optimal individual dosage regimen according to the ABBOTTBASE Pharmacokinetic system. In this subgroup, real peak levels did not achieve optimal efficacy value (Tab. 2).

Table 2.Charactericticsofthepatients in the subgroups and pharmacokinetic parameters according to peak concentration after a dosage adjustment in the second measurement

\begin{tabular}{|c|c|c|}
\hline $\begin{array}{c}\text { Characteristics of the } \\
\text { patients } \\
\text { and pharmacokinetic } \\
\text { parameters }\end{array}$ & $\begin{array}{c}\text { Subgroup A } \\
\text { The patients with optimal } \\
\text { peak levels }\end{array}$ & $\begin{array}{c}\text { Subgroup B } \\
\text { The patients with low peak } \\
\text { levels }\end{array}$ \\
\hline Patients (n) & 34 & 15 \\
\hline Mean age \pm SD (year) & $57.7 \pm 18.7$ & $53.9 \pm 18.5$ \\
\hline
\end{tabular}




\begin{tabular}{|c|c|c|}
\hline $\mathbf{A B W} \pm \mathbf{S D}(\mathbf{k g})$ & $88.1 \pm 23.1$ & $104.4 \pm 39.1$ \\
\hline $\mathbf{L B W} \pm \mathbf{S D}(\mathbf{k g})$ & $63.6 \pm 7.6$ & $71.9 \pm 6.2^{* *}$ \\
\hline $\mathbf{I B W} \pm \mathbf{S D}(\mathbf{k g})$ & $66.1 \pm 8.5$ & $75.8 \pm 8.4^{* *}$ \\
\hline height $\pm \mathbf{S D}(\mathbf{c m})$ & $170.8 \pm 9.2$ & $181.0 \pm 9.1^{* *}$ \\
\hline $\mathbf{B M I} \pm \mathbf{S D}\left(\mathbf{k g} / \mathbf{m}^{2}\right)$ & $30.0 \pm 6.9$ & $32.0 \pm 9.3$ \\
\hline $\mathbf{C r} \pm \mathbf{S D}(\boldsymbol{\mu m o l} / \mathbf{L})$ & $91.23 \pm 40.41$ & $2,17 \pm 2.44$ \\
\hline $\mathbf{C G} \mathbf{C r C} \pm \mathbf{S D}(\mathbf{m L} / \mathbf{s})$ & $1.80 \pm 0.76$ & $17,98 \pm 1.53^{* *}$ \\
\hline total Vd $\pm \mathbf{S D}(\mathbf{L})$ & $15.90 \pm 2.53$ & $4,918 \pm 1.946$ \\
\hline total cl $\pm \mathbf{S D}(\mathbf{L} / \mathbf{h r})$ & $3.990 \pm 1.308$ & $0,275 \pm 0.117$ \\
\hline $\mathbf{k}_{\mathbf{e}} \pm \mathbf{S D}(\mathbf{1} / \mathbf{h r})$ & $0.254 \pm 0.105$ & \\
\hline
\end{tabular}

$\mathrm{n}$ - number of patients, $\mathrm{SD}$ - standard deviation, $\mathrm{ClCr}$ - clearance creatinine, $\mathrm{ABW}$ - actual body weight, LBW - lean body weight, IBW - ideal body weight, height, BMI - body mass index, Cr -creatinine, CG$\mathrm{ClCr}-\mathrm{Cocroft}$ and Gaultcreatinine clearance, total $\mathrm{Vd}$ - total volume of distribution, total $\mathrm{Cl}$ - total clearance, $\mathrm{k}_{\mathrm{e}}-$ elimination rate constant,

${ }^{*} p<0.05 \mathrm{CG}-\mathrm{CrCl}$-subgroup B vs. subgroup A, according to unpaired Student's t-test

** $\mathrm{p}<0.001$ total Vd subgroup B vs. subgroup A, according to unpaired Student's t-test

The subgroup B includes younger males with higher value: ABW, LBW, IBW, BMI, creatinine, pharmacokinetic parameters and with better renal function. We have a problem to determine the optimal dosage regimen for these subgroups. Although we used ABBOTBASE Pharmacokinetic system peak levels that were not optimal after the second measurement. BMI supposed these patients were obese.

Obese patients appear to have a larger muscle mass than would be predicted when using height in the IBW equation [6, 7]. Intuitively, such approaches seem reasonable since creatinine is produced in muscle, not fat tissue. One suggestion that might help in determining a reasonable weight is to avoid use of only standards and to visually examine the patients. A body builder would clearly be expected to produce more creatinine on a daily basis [9].

Many authors referred about low dosage confirmed by low peak concentrations in practice. Desoky and Klotz [10] had 40\% patients with low dosage in their study. Average creatinine clearance was $1.9 \mathrm{~mL} / \mathrm{s}$. Thomson [11] refers 53\% patients with low peak concentrations, who receive conventional doses. $77 \%$ patients had low peak levels in the first measurement in our observation study during year 2001 [12, 13]. In 1990, Ismail et al. referenced 194 patients. Initial concentrations were appropriate in only 69 patients (35\%) [14]. In 1997 Ismail et al. reported on a 6-year follow up audit. The audit involved 590 patients. Peak concentrations were within the therapeutic range in $65 \%$ of 
the patients at first monitoring. After dosage adjustment, $81 \%$ of the peak concentrations were within the therapeutic range [15].

The problem with gentamicin dosage regimens for younger patients with higher ABW, LBW, IBW, BMI, creatinine, pharmacokinetic parameters and with good renal function is not solved yet. The determination of appropriate dose after second measurement can be late. The best solution would be to determine the optimal dose as soon as possible.

There are guidelines for patients with low creatinine clearance in the official Summary of Product Characteristics (SPC) and in a number of references, but they are not meant for obese patients and for young patients with high creatinine clearance [16]. Dosing of aminoglycosides is typically based on total body weight. However, the most appropriate alternative body size descriptor for dosing aminoglycosides at the extremes of weight is not known [17].Unfortunately obese subjects are often excluded from clinical trials during the drug development process [18]. Physiological changes associated with obesity can potentially alter the clearance of commonly used drugs [19]. Existing methods for predicting creatinine clearance provide accurate estimates for normal weight patients but not for patients who are obese [20]. Management of obese patients presents a challenge in terms of what weight to use for dose calculation. In such cases, empirical dosing with measurement of peak and trough concentrations, and dose individualization may be more appropriate [21].

The Pharmacokinetic system - the ABBOTBASE uses LBW, which is almost always lower than IBW. It is a problem with younger patients with higher ABW and with the optimal renal functions. The calculated dosage according to pharmacokinetic parameters was lower than dosage that was needed for these patients. The subgroup B includes only males with average age of 53 years, higher height and higher weight than the subgroup A. The value of creatinine was higher. We can suppose they have more muscle mass and less fat than the LBW value required in the ABBOTTBASE. If clinical pharmacists use only the ABBOTTBASE and official SPC for adjustment dosage regimens, the patients will receive low dosage. We had to adjust dosage regimens, especially according to TDM and experience. We allowed the greater doses of gentamicin for these patients. Measurements of aminoglycosides concentration in serum are used to individualise dosage regimens with the goal of attaining the desired therapeutic range as quickly as possible [22]. The dosage regimens in our subgroup B were: $160 \mathrm{mg}$ every 12 hours, $200 \mathrm{mg}$ every 12 hours and once $220 \mathrm{mg}$ every $12 \mathrm{hr}$ than were suggested by clinical pharmacists.

\section{CONCLUSION}

Our results showed a problem that the patients with low peak levels of gentamicin are more frequent than patients with toxic adverse effects in clinical practice. Due to concerns of gentamicin nephrotoxicity, patients are prescribed low doses. Especially, these are patients with higher values: ABW, LBW, IBW, BMI, creatinine, pharmacokinetic parameters and with good renal function. Determination of an optimal dosage for these patients is not easy. Missing are the recommendations of appropriate 
doses so that we can choose an optimal dose as soon as possible. The problem with the gentamicin dosage regimens for these patients is not solved yet. The clinical pharmacists have to adjust dosage regimens, especially according to TDM and experience. TDM of gentamicin helps us to determine and individualise optimal doses for the patients. The results of the study confirmed that the clinical pharmacists must adjust dose regimen not only for patients who require reduced doses but more often for patients who require higher doses than are commonly used in clinical practice. These patients are at risk of underdosing.

\section{REFERENCES}

1. Bertino, J., S., Jr. - RODVOLD, K., A., DeSTACHE, C., J.: Cost consideration in therapeutic drug monitoring of aminoglycosides. Clin Pharmacokinet, 26, 1, 1994, p. 71 81.

2. ROBERTS, J., A. - PATERSON, D., L.- MARTIN, J., H.: Therapeutic drug monitoring of antimicrobials. Br J Clin Pharmacol, 73, 1, 2012, p. 27 - 36.

3. CONNORS, J., E. - DIPIRO J., T. - SISLEY J., F.: Use of serum concentration in surgical patients. Am J Surg 156, 1, 1988, p. 68 - 76.

4. MIGNAVAL, F. - FONTAINE, P., A. - RICHÉ, A. - NOWAK, C. - CANCEL, D. LEMAITRE, F.: A Priori prediction of gentamicin peak concentrations: Use of a simple and practical tool. PatholBiol (Paris) 59, 2, 2011, p. $79-82$.

5. VARON, J. - MARIK, P.: Management of the Obese Critically Ill Patient. Crit Care Clin $17,1,2001$, p. $187-200$.

6. ROBERT, S. - ZAROWITZ, B.: Is there a reliable index of glomerular filtration rate in critically ill patients? DICP Ann Pharmacother 25, 2, 1991, p. $169-178$.

7. SAWYER W., T. - CANADAY, B., R. - POE, T., E.: Variables affecting creatinine prediction. Am J Hosp Pharm 40, 12, 1983,p. 2175 -90.

8. EVANS, W., E-OELRICH, M. - HOLTZ, D., W.: Therapeutic Drug Monitoring. Clinical Guide.2 ed. Wiesbaden, Germany.ABBOTT Laboratory, Diagnostic Division, 1994, 160 p.

9. MURPHY, J., E.: Clinical Pharmacokinetics. $4^{\text {th }}$ edition Bethesda, Maryland: American Society Health - System Pharmacists, Publishing, 2008, p. 463.

10. DESOKY, E., E. - KLOTZ, U.: Value, limitations and clinical impact of therapeutic drug monitoring in adults. Drug Invest 6, 3, 1993, p. $127-136$.

11. THOMSON, A., H. - DUNCAN, N. - SILVERSTEIN, B. - ALCOCK, S. - JODRELL, D.: Development of guide lines for gentamicin dosing. J Antimicrob Chemother 38, 5, 1996, p. $885-893$.

12. GÖBOÖVÁ, M. - MAGULOVÁ, L.: Use of TDM for optimal gentamicin therapy. Acta Chemother 10, 4-5, 2001, p.89 - 93.

13. MAGULOVÁ, L. - VIRÁG, L. - GÖBOÖVÁ, M.: Interpretation of results of therapeutic monitoring levels of gentamicin. (In Slovak). Acta Chemother 16, 5, 2006, p. $49-50$.

14. ISMAIL, R. - SARRRIFF, A. - ABDUL RAHMAN, A., F.: Therapeutic drug monitoring for gentamicin in Hospital Universiti Sains Malaysia. Med J Malaysia, 45, 1, 1990, p. 5764.

15. ISMAIL, R. - HAQ, A., H. - RAHMAN, A., F.: Therapeutic drug monitoring of gentamicin: a 6-year follow-up audit. J Clin Ther 22, 1, 2001, p. 21-25.

16. LAM, F.,Y., W. - Banerji, S. - Hatfield, C. - Talbert, R., L.: Principles of drug administration in renal insufficiency. Clin Pharmacokinetic 32, 1, 1997, p. 30 - 57. 
17. PAI, M., P. - NAFZIGER, A., N.- BERTINO, J., S.: Simplified estimation of aminoglycoside pharmacokinetics in underweight and obese adult patients. Antimicrob Agents Chemother 55, 9, 2011, p. 4006 - 4011.

18. LEYKIN, Y. - MIOTTO, L. - PELLIS, T.: Pharmacokinetic considerations in the obese. Best Pract Res Clin Anaesthesiol 25, 1, 2011, p. 27 -36.

19. PAI, M., P.: Estimating the glomerular filtration rate in obese adult patients for drug dosing. Adv Chronic Kidney Dis. 17, 5, 2010, p. 53 - 62.

20. SALAZAR, D., E. - CORCORAN, G., B.: Predicting creatinine clearance and renal drug clearance in obese patients from estimated fat free body mass. Am J Med 84, 6, 1988, p. $1053-1060$.

21. DHILlON, S. - KOSTRZEWSKI, A.: Clinical Pharmacokinetics. $1^{\text {st }}$ edition London, Chicago: Pharmaceutical Press, Publishing, 2006, p. 262.

22. TOD, M., M. - PADOIN, C. - PETITJEAN, O.: Individualising aminoglycosides dosage regimens after therapeutic drug monitoring: simple or complex pharmacokinetic methods? Clin Pharmacokinet 40, 11, 2001, p. $803-814$.

\title{
PROBLÉM NÍZKYCH VRCHOLOVÝCH KONCENTRÁCII GENTAMICÍNU V KLINICKEJ PRAXI
}

\author{
${ }^{1,2}$ Göböová, M. $-{ }^{2}$ Kuželová, $M-{ }^{2}$ Foltánová, $T$. \\ ${ }^{1}$ Nemocnica Nitra, Oddelenie klinickej farmakológie \\ ${ }^{2}$ Univerzita Komenského v Bratislave, Farmaceutická fakulta, Katedra farmakológie a toxikológie
}

Aminoglykozidové antibiotiká sú vel'mi dôležitými antibiotikami v liečbe gram negatívnych infekcií. Účinok aminoglykozidových antibiotík je závislý na ich koncentrácii. Toxicita gentamicínu je dobre známa, v klinickej praxi sa však stretávame s pacientmi, ktorí dostávajú nedostatočné dávky. Ciel’om tejto práce bolo poukázat' na pretrvávajúci problém poddávkovania gentamicínom, ktorý potvrdzujú nízke vrcholové koncentrácie a nájst' súvislost' medzi farmakokinetickými parametrami, obličkovými funkciami, telesnou hmotnostou a nízkymi vrcholovými koncentráciami.

V práci sme analyzovali údaje o 68 pacientoch, ktorí sa liečili gentamicínom počas jedného roka (august 2010 - august 2011). Terapeutické monitorovanie hladín sa uskutočnilo u všetkých pacientov. Reziduálne a vrcholové hladiny gentamicínu sa merali analytickou metódou FPIA (flurescenčnou polarizačnou imunoanalýzou) na analyzátore AxSYM firmy ABBOTT. Pacientov sme rozdelili do 3 skupín.

Celkovo $13(19 \%)$ malo vysoké reziduálne hladiny a optimálne vrcholové koncentrácie gentamicínu. Iba $6(9 \%)$ pacientov malo pri prvom meraní sérových koncentrácí́ optimálne obe hladiny. Tretia skupina zahŕňala 49 pacientov $(72 \%)$. Títo pacienti mali optimálne reziduálne hladiny, ale nízke vrcholové hladiny pri prvom meraní. Až 34 pacientov (28 mužov, 6 žien) z 
tretej skupiny malo optimálne vrcholové koncentrácie po úprave dávkových režimov pri druhom meraní. U 15 pacientov (len muži) sa nedosiahli optimálne vrcholové koncentrácie pri druhom meraní ani po úprave dávky.

V klinickej praxi sa častejšie vyskytujú pacienti snízkymi vrcholovými hladinami gentamicínu ako pacienti s nežiaducimi účinkami. Sú to pacienti s vyššími hodnotami telesnej hmotnosti, farmakokinetických parametrov a dobrými renálnymi funkciami. Určit' optimálne dávkové režimy pre týchto pacientov nie je l’ahké. Chýbajú odporúčania vhodných dávok, aby sa mohla čo najskôr zvolit' optimálna dávka. Riešenie tohto problému sa ešte nenašlo. Klinickí farmaceuti upravujú dávkové režimy pre týchto pacientov podl'a TDM (terapeutické monitorovanie hladín liekov) a klinických skúseností. Z výsledkov našej štúdie vyplýva, že klinickí farmaceuti musia upravovat' dávky nielen pacientom, ktorí potrebujú redukované dávky ale častejšie pacientom, ktorí potrebujú vyššie dávky ako sa bežne používajú v klinickej praxi. Týmto pacientom hrozí riziko poddávkovania gentamicínu.

Acta Fac. Pharm. Univ. Comen., Suppl., 2012, VI, p. 35 - 43. 